\title{
KONTESTASI PENAFSIRAN IDEOLOGIS DI WEBSITE: STUDI ATAS AYAT-AYAT MUTASHĀBIHĀT SIFAT ALLAH DALAM SITUS ISLAM SALAFI DAN NAHDLATUL ULAMA
}

\author{
Umarul Faruq \\ UIN Sunan Ampel, Surabaya \\ abuhafsh18@gmail.com
}

\begin{abstract}
Absract: This article aims to figure out the contesting ideological exegesis of the mutashābihāt verses in the sifät of Allah from two Islamic sect in Indonesia, Salafi Islam and Nahdlatul Ulama. By using a comparative-qualitative approach to the data on the two streams on the website, this article attempts to describe the interpretations, views, and ideological tendencies of the two schools. Finally, this research concludes that salafi Islam tends to interpret mutashabihat verses zahir without using takwil. Meanwhile, Nahdlatul Ulama carried out takwil on mutashābihāt verses, especially those related to verses that had the connotation of jismiyyah. Although they have differences in interpreting mutashābihāt, they both avoid equating Allah with his being. This article emphasizes that the Salafi Islamic interpretation of the Qur'an and hadith tends to be textual rather than the Nahdlatul Ulama 'which is more contextual.
\end{abstract}

Keywords: mutashäbihät verses; Islamic Salafism; Nahdlatul Ulama.

\section{Pendahuluan}

Di era globalisasi dan perkembangan zaman seperti saat ini menuntut semua lini berkembang cepat, termasuk media baca dan media tulis. Pada saat ini, hampir semua umat Islam memandang bahwa media adalah saluran yang netral dan bebas, dimana semua pihak dapat menyampaikan segala kepentingannya serta menggali informasi secara luas dengan bebas. Oleh karenanya, banyak umat Islam mulai mengambil posisi masing-masing untuk mencapai 
tujuannya. Media juga banyak membantu beberapa kelompok dominan menyapaikan gagasan pribadi yang membela kelompoknya. Sebagaimana dilakukan oleh beberapa ormas Islam Indonesia, semisal; Islam Salafi dan Nahdlatul Ulama ${ }^{1}$ untuk menyampaikan gagasan, pemikiran, dan mengontrol kelompok mereka bahkan mengontrol antar kelompok. Media bisa juga dikatakan sebuah arena peperangan ideologi antarkelas, saat ini ia merupakan ruang pertarungan antar keduanya juga antar kelompok lain yang saling kontra.

Cara berfikir yang berbeda antara keduanya sering kali menyebabkan pemahaman yang bertentangan. Misalnya tentang ayat mutashäbihät, Konsep Nahdlatul Ulama' (NU); organisasi yang mengikuti Imam Asy'ari dan Imam Al-Maturidi dalam hal Aqidah ini memilih untuk tidak menafsiri ayat mutashäbihät mengenai sifat dengan teks dhahir, namun perlu adanya beberapa pen-ta'mil-an, ${ }^{2}$ sebagaimana Ulama' dari kalangan Asy'ari baik salaf maupun khalaf berbeda metode dalam menyikapi ayat mutashäbihat yang berkaitan dengan sifat Allah. Hal itu juga dikarenakan dalam alQur'an terdapat beberapa ayat yang menafikan Allah swt memiliki

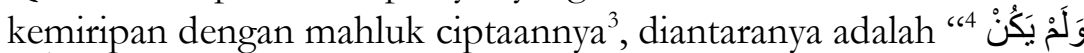

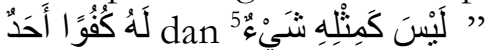

Dengan langkah yang dipilih oleh NU, Firanda Andirja, salah satu tokoh Salafi di Indonesia, dalam ceramahnya di youtube mengatakan bahwa metode tafwìd dan ta'wïl yang dilakukan oleh Asy 'Ariyah itu sesat. Menurutnya, hal itu menandakan bahwa ayat al-qur'an bukan lah menggunakan bahasa yang jelas dan bukan petunjuk bagi seluruh manusia, dengan cara tersebut pula

\footnotetext{
${ }^{1}$ Nahdlatul Ulama sendiri adalah suatu organisasi yang salah satu faktor terbentuknya adalah untuk membendung ajaran Wahabi yang memiliki dampak dihilangkannya beberapa praktik peribadatan pengikut paham Ablussunnah Waljamaah. (Baca : Tim Aswaja NU Center PWNU Jawa Timur, Khazanah ASW AJA, (Surabaya : Aswaja NU Center PWNU Jawa Timur, t.th), 408.

2 Untuk lebih jelanya, baca : Abd al-Fattāh bin Șālih, al-Tajsìm Wa AlMujassimah, 2010 M (Beirūt: Resalah Publisher, 2010). 58-61

3 Disadur dari https://asysyariah.com/dua-tangan-allah/ diakses pada 06-052021

${ }^{4}$ Q.S Al-Ihlash $112: 4$

${ }^{5}$ Q.S As-Syura $42: 11$
}

154 | Mushaf: Jurnal Tafsir Berwawasan Keindonesiaan Volume 1. Nomor 2, Juni 2021. 
cenderung pada penolakan teks al-qur'an. ${ }^{6}$ Baginya menggunakan metode ta'wil juga tidak sejalan dengan pendapat ablussunnab waljamäah. ${ }^{\top}$

Penelitian penolakan dari masing-masing kelompok sebenarnya sudah banyak ditulis oleh sejumlah peneliti, baik itu langsung atau sekedar penguatan akidah internal, akan tetapi hingga hari ini tidak ditemukan secara langsung penelitian yang membandingkan pendapat keduanya, terlebih dari tulisan yang tertuang di media saat ini. Oleh karenanya, artikel ini mencoba untuk menyaring beberapa pendapat tersebut sebagai sumber primer yang kemudian dipadukan dan dibandingkan, begitu juga disesuaikan dengan beberapa referensi sekunder yang lain mengenai pendapat ulama mu'tabar

\section{Definisi Global Ayat-Ayat Mutashābihāt}

Mutashäbihät secara bahasa ialah bentuk derivasi dari fi'il māḍi tashäbuh, yakni dua perkara yang serupa sebagian dengan sebagian lainnya. ${ }^{8}$ Mengenai lafadz mutashābihāt ini dapat ditemukan di beberapa ayat dalam al-Qur'an, diantaranya bermakna; "serupa" seperti dalam QS. al-Nisā':157, Al-Ra'd: 16, QS. al-Baqarah: 25 dan 118, al-An'ām: 99 dan 141 dan QS. Al-Zumar: 23. Dan bermakna "samar/tidak ada kejelasan" seperti dalam QS. Al-Baqarah: 70 atau yang secara langsung meyebutkan tentang ayat-ayat mutashäbibāt seperti QS. Ali-Imrān: 7. Dari semua makna tersebut tidak bertentangan, namun ditinjau dari susunan bahasa menghandaki makna berbeda tetapi satu maksud, yaitu ; dua perkara yang tidak bisa dibedakan dikarenakan keduanya memiliki makna serupa jika dilihat dari segi indrawi namun tidak secara hakiki. ${ }^{9}$

Sedangkan secara istilah, menurut ulama usül, mutashäbihät ialah sesuatu yang penunjukan maknanya tersembunyi oleh dirinya,

\footnotetext{
${ }^{6}$ Ceramahnya bisadi akses di Youtube https://www.youtube.com/watch?v=0nwEUxcqHqA yang Dipublikasikan tanggal 23-April-2021.

7 Ibnu Bāz, Majmu’ Fatāwa Ibnu Bin Baz, Juz 3, n.d. 74.

8 Syauqi Daif, Mu’jam Al-Wasit (Mesir: Maktabah Syurūq Ad-Dauliyyah, 1425). 471.

9 Al-Aṣfahānī, Mufradāt Fì Gharìb al-Qur'ān, Juz 1 (Damaskus: Dār al-Qalam, 1412). 443
} 
dan sulit untuk diketahui kepastiannya kecuali dikembalikan pada pemilik syariat (Allah SWT). Sedangkan menurut ulama' tafsir ialah sesuatu yang tidak jelas secara makna dhahirnya serta berbedabeda maknannya. Dan menurut Ulama' kalam; ialah suatu yang diketahui maknanya dan mustahil untuk mengetahui makna yg dikehendaki sebenarnya, seperti ayat yang menerangkan tentang shifat. ${ }^{10}$ Abdul Karim Zaidan dalam kitabnya al-Wajir. fi Ușül alFiqh menjelaskan bahwa mutashäbihät adalah lafal yang maknanya tersembunyi, sighah-nya tidak menunjukkan makna tersebut dan tidak ada jalan untuk mengetahuinya karena tidak terdapat qainah yang menyingkap makna tersebut. ${ }^{11}$

Mayoritas ulama' berbeda pendapat dalam mendefinisikan ayat mutashäbihät, sebagaimana beberapa pendapat tersebut dikutip oleh al-Zarqānī dalam karyanya ${ }^{12}$, yakni:

1. Mutashäbihät adalah ayat yang samar, yang tidak bisa diketahui baik secara aqli atau naqli, hanya Allah swt saja yang mengetahuinya, seperti mengenai kapan hari kiamat tiba, hurufhuruf yang terputus di awal surat. Menurut al-Alusi, pendapat ini adalah menurut ulama' Hanafiyah.

2. Mutashābih adalah ayat yang maknanya hanya diketahui oleh Allah swt saja. Seperti mengenai kapan hari kiamat tiba, hurufhuruf yang terputus di awal surat. Dan pendapat ini dinisbatkan pada ulama ablussunnah dan juga menjadi pendapat yang terpilih diantaranya.

3. Mutashābihāt adalah ayat yang elastis, bisa dibawa ke berbagai aspek. Dan ini adalah pendapat Ibnu Abbas dan beberapa ulama' usūll.

4. Mutashàbihāt adalah ayat yang tidak bisa memahami dengan hanya dirinya sendiri, akan tetapi ia butuh penjelasan. Terkadang diterangkan begini dan juga kadang begitu, sesuai perbedaan dalam menakwilinya. Dan pendapat ini disandarkan kepada Imam Ahmad RA.

10 Khalid Abdurrahman Al-Akk, Usul al-Tafsìr wa Qawäidubu (Beirūt: Dar alNafāis, 1986). 291

11 Abdul Karim Zaidan, al-Wajī̌ Fì Ușūl Al-Fiqh, (Beirut: Muassasah ar-Risālah Nāshirūn, 2012). 280

12 Al-Zarqānī, Manāḥi al-'Irfān, Juz 2 (Beirūt: Dar al-Kitāb al-Arabī, 1995). 20152016. 
5. Ayat mutashābihāt adalah ayat yang maknanya tidak bisa dijangkau hanya dengan ilmu dengan menelusuri bahasa, kecuali dengan adanya bebrapa tanda dan ayat yang berkesinambungan. Pendapat ini dinisbatkan kepada Imam alHaramain.

6. Ayat mutashābihāt adalah ayat yang sulit untuk dipahami seperti beberapa ayat yang memiliki keserupaan pada hak Allah swt. Pendapat ini menurut ulama muta'ahhirin dan ada juga yang mengatakan bahwa pendapat ini menurut syaikh at-Thibi.

Semua ulama' berbeda pendapat sesuai posisinya masingmasing. Ulama' kalam membawakan contoh ayat mutashäbihät semisal sifat Allah Swt. Untuk ini, dikarenakan mengenai sifat kita hanya bisa mereka pahami namun tidak bisa mengetahui secara utuh apa yang sebenarnya dikehendaki oleh Allah swt. Diantaranya juga adalah Ulama Ushul, ia mendefinisikan mutashābihāt dari segi bagaimana pesan hukum ayat itu. Dan yang menjadi titik fokus adalah pendefinisan tentangnya dari ulama tafsir, yaitu sesuatu yang tidak jelas berarah kemana sehingga memunculkan berbagai macam tafsir makna. Namun pada intinya, semua bertitik tekan pada maksud "ayat yang tidak menunjukkan suatu tujuan yang jelas". ${ }^{13}$

Al-Zarqani membagi ayat-ayat mutashābihāt menjadi 3 bagian, yaitu :

1. Ayat mutashäbihāt adalah ayat yang tidak bisa dipahami oleh semua orang, seperti ayat tentang dzat Allah swt, beberapa sifat-sifatnya, dan tentang kapan terjadinya hari kiamat.

2. Ayat mutashäbihàt adalah ayat yang tidak bisa dipahami dengan hanya melaui cara belajar dan diskusi, seperti ayat mutashābihāt yang sengaja diungkapkan secara ringkas, sederhana dan tertib.

3. Ayat mutashäbihät adalah ayat yang hanya bisa dipahami oleh orang-orang tertentu saja, tidak secara keseluruhan manusia. Seperti ayat yang memiliki makna tinggi yang disandarkan

13 Abd Basid, "PENINGKATAN TARIF HIDUP LAYAK MELALUI PRODUKTIVITAS BEKERJA PERSPEKTIF AL-QUR'AN," Jurnal Studi Ilmu-Ilmu Al-Qur'an Dan Hadis 21, no. 1 (2020): 173-92. 
kepada orang-orang bersih, hal ini diperlukan kesungguhan dalam mentadabburi kitab Allah swt. ${ }^{14}$

\section{Biografi Islam Salafi dan Aswaja NU Biografi dan Sketsa Tafsir Islam Salafi}

Kata Salafi ${ }^{15}$ pada asalnya adalah sebuah bentuk penisbatan kepada as-salaf. ${ }^{16}$ Kata as-salaf sendiri secara bahasa bermakna orang yang mendahului atau hidup sebelum zaman kita. ${ }^{17}$ Sedangkan secara terminologis as-salaf adalah 3 generasi yang dibatasi oleh sebuah penjelasan Rasulullah SAW. dalam haditsnya, yang artinya "Sebaikbaik orang adalah masaku,kemudian orang-orang generasi berikutnya, kemudian generasi berikutnya."18

Muhammad Abu Zahrah dalam karyanya menyebutkan, bahwa Salafiyyah atau Salafi adalah salah satu golongan yang dicetuskan pertama kali oleh Ibnu Taimiyah pada abad ke 7 Hijriah, yang kemudian pada abad ke 12 dihidupkan kembali oleh muridnya; Muhammad bin Abdul Wahhab, sejak itu pula Wahabi selalu saja menyebut dirinya dengan istilah "Salafiyyah". ${ }^{19}$

Negeri Indonesia belumlah lama mengenal dakwah salafiyyah yang murni dan benar, tidak lebih dari 10 tahun yang

${ }^{14}$ Ahmad Fawaid and Thoriqotul Faizah, "A Sociolinguistic Analysis of Sword Verses," Al Quds Jurnal Studi Al-Qur'an Dan Hadis 5 (2021): 119-40, https://doi.org/1 http://dx.doi.org/10.29240/alquds.v5i1.2315.

15 Jika berbicara sebatas "salaf", maka disini berbicara sebagaimana makna secara bahasa (terdahulu), namun disini - salafi- berarti nisbi atau penyandaran terhadap masa salaf (terahulu). (Baca: Said Ramadhan Al-Buthi, Al-Salafiyyah Marhalah Zamaaniyyah Mubaarokah Lā Madžhab Islami (Damaskus: Dar al-Fikr, 1996). 9.

${ }^{16}$ Dari kata inilah kemudian muncul berbagai kata, seperti Salafusshalih, Salafiyyin, Salafiyyah dan sebagainya, yang pada intinya akan kembali kepada 3 generasi terbaik (Nabi dan Sahabat, Tabi'in dan tabi' at-Tabi'in). Salaf atau salafiyah memiliki nama- nama lain, diantaranya al-Jama'ah, Ablul Sunnab wal Jama" ah, Ablul Atsar, al-Firqatun Najizah, al-Thaifah al-Manshurah. (Baca: Muhammadin, "PANDANGAN ULAMA TERHADAP DAKWAH SALAFIYAH," JLA 53, no. 4 (2017): 130.

17 Abu Fadl Muhammad ibnu Manzhur, Qamus Lisan Al-Arab, jilid 6 (Beirut: Dar as-S \}adir, 1410). 330.

18 Imam Muslim, Shahih Muslim, Juz 4 (Beirūt: Dar Ihya al-Turats al-'Arabī, n.d.). 1963.

19 Muhammad Abu Zahrah, Tariḥ al-Madzāhib al-Islāmiyyah Fī al-Siyāsah Wa Al'Aqüid, Wa Tarikh Al-Madz̧ābib al-Fiqhiyyah (Kairo: Dar al-Fikr al-'Arabī, t.th.). 177. 
lalu melalui perantaraan sebagian putra-putra Indonesia yang lulus dari Universitas Islam Madinah, dan mereka terpengaruh dengan para ulama salafiyyin di Madinah. Pengaruh yang jelas dan penyebaran yang luas dakwah salafiyyah ini juga timbul dari penyebaran dan penerjemahan kitab-kitab salafiyyah ke dalam bahasa Indonesia dari para ulama salaf, baik yang lampau maupun ulama pada saat ini. Dari buku-buku itulah mereka mengenal manhaj salaf yang benar. Berada pada bagian yang terdepan dalam hal ini adalah kitab-kitab Syaikhuna Al Imam Sayyidul Mubadditsin (Pemimpin ahli hadits) zaman ini, Abu Abdurrabman Mubammad Nashiruddin Al Albani dan murid- murid beliau yang mubkblis, kemudian buku-buku Al Allaamah Syaikh Abdul Aziz bin Abdullab bin Baz dan Al Allaamah Al Imam ahli fikih zaman ini Syaikh Muhammad bin Shalih Al Utsaimin. ${ }^{20}$ Sungguh kitab-kitab, karangankarangan dan fatwa-fatwa mereka tersebar di seluruh jazirah Indonesia, dan penduduk negeri ini benar-benar mendapatkan manfaat darinya. Selain itu, demikian pula kitab-kitab Syaikhul Islam Ibnu Taimiyyah dan murid beliau Al Imam Ibnu Qoyyim Al Jauriyah dan kitab-kitab Syaikhul Islam Muhammad bin Abdul Wahhab dan anak-anak beserta cucu-cucu beliau yang shalih.

Mengenai bagaimana metode Salafi dalam menafsirkan alQur'an, hal ini tidak akan terlalu jauh dari latar belakang beberapa tokoh Islam Salafi. Mengenai ini, banyak sekali tafsir yang disinyalir berpaham Salafi, dan diantara beberapa tafsir tersebut adalah kitab tafsir karya Ibnu Taimiyah yang bernama Tafsir AlKabir, yang mana pendiri paham Salafi ini banyak dipengaruhi olehnya. Adapun bagaimana manhaj atau metodenya ${ }^{21}$, yakni sebagai berikut :

1. Hampir beberapa tafsir Salafi membahas mereka yang Ahlul Bid'ah dan yang mengikuti hal yang subhat adalah sesat. Ini adalah hal yang sangat mungkin terjadi, melihat dari beberapa visi-misi dari Islam Salafi sendiri.

2. Membahas beberapa pendapat ulama' tentang ayat Asma' dan S\}ifat Allah termasuk ayat yang mutashäbihäat atau bukan.

20 Ahmad Fawaid and Nafi'ah Mardlatillah, "Bias Ideologis Tafsir Hizb AlTahrīr," MAGHZA: Jurnal Ilmu Al-Qur'an Dan Tafsir 5, no. 2 (2020): 184-209, https://doi.org/10.24090/maghza.v5i2.4243.

${ }^{21}$ Muhammad 'Ali Iyāzī, al-Mufassirūn, t.th. 245. 
Diantara beberapa term keilmuan yang termuat dalam alQur'an, memang term inilah yang sering memiliki perbedaan konsep antara Islam Salaf dengan organisasi lainya.

3. Umumnya, tafsir Salafi tidak terlalu mengedepankan rasio, akan tetapi sangat mengedepankan dalil naqli, Jadi boleh dikatakan segala hal yang bertentangan dengan Naqli atau yang tidak ada pejelasannya dalam dalil Naqli akan ia tolak.

Umumnya tafsir Salafi tak jauh berbeda dengan tafsir Ibnu Taimiyah ini, terkadang tidak semua ayat termuat dalam tafsirnya, hanya beberapa pertanyaan yang dianggap perlu dan penting untuk di angkat menjadi tema dan menjadi permasalahan saat itu. ${ }^{22}$ Dalam penafsiran ayat mutashäbibāt fi al-sifat, tentu dalam hal ini melibatkan masalah akidah dan keyakinan sebagai furü'iyah, sebagaimana yang sudah diungkapkan oleh al-Zarkashi yang telah penulis kutip di atas bahwa dalam ayat ini terdapat tiga versi penafsiran yang diantaranya adalah mushabbihab/mujassimah, yakni suatu golongan yang memahami al-Qur'an dan hadis secara tekstual dan tidak menggunakan perangkat pengetahuan yang biasa digunakan ulama untuk memahami al-Qur'an dan hadis: misalnya, usül fikih, ilmu tafsir, ilmu hadits, ilmu bahasa, dan lain-lain. ${ }^{23}$

Mengenai aqidah sifat-sifat Allah, kaum Salafi menetapkan apa-apa yang Allah dan Rasulnya telah tetapkan atas diri$\mathrm{Nya}^{24}$ dengan tanpa tahrif ${ }^{25}$, dan ta' $^{\prime}$ bi $^{-26}$, serta tanpa takyif. ${ }^{27}$ mereka menetapkan bahwa Allah memiliki sifat cinta dan benci, murka

\footnotetext{
$22 \mathrm{Ibid}$

23 Tim Harakah Islamiyah, Buku Pintar Salafi-Wahabi (Harakah Islamiyah, n.d.). 24.

${ }^{24}$ Ahmad Atabik, "CORAK TAFSIR AQIDAH (Kajian Komparatif Penafsiran Ayat-Ayat Aqidah)," ESENSLA: Jurnal Ilmu-Ilmu Ushuluddin 17, no. 2 (2016): 209, https://doi.org/10.14421/esensia.v17i2.1288.

${ }^{25}$ Juga disebut sebagai ta'mīl menurut Salafi, yaitu: merubah lafaz nama dan sifat, atau merubah maknanya, atau menyelewengkan dari makna sebenarnya. (Baca : Ahmad Atabik, Ibid.)

${ }^{26}$ Adalah mengilangkan dan menafikan Sifat-Sifat Allah atau mengingkari seluruh atau sebagian Sifat-Sifat Allah. (Baca : Ahmad Atabik, Ibid.)

${ }^{27}$ Adalah menerangkan keadaan yang ada padanya

sifat atau mempertanyakan: Bagaimana sifat Allah itu? Atau menentukan sifat Allah itu hakekatnya begini dan begitu, seperti menanyatakan: Bagaimana Allah bersemayașm. (Baca : Ahmad Atabik, Ibid.)
} 
dan ridha, memanggil, berbicara, turun saat kegelapan, berdiam diri di 'ars, memiliki wajah sampai memiliki tangan dengan tanpa ta'wil juga tanpa menafsirkan diluar teks nyata. ${ }^{28}$ Selagipun mereka menyifati apa yang telah Allah sifati pada dirinya begitu juga yang dilakukan oleh Rasulullah, mereka memiliki tujuan secara global, yakni tidak menyamakan Allah dengan mahluk ciptaan-nya. ${ }^{29}$

Oleh karena itu, Muhammad Abu Zahrah menyimpulkan, yang artinya : Berarti dengan semua itu, mereka meyakini bahwa Ulama Salaf menetapkan apa yang sudah ada dalam al-Qur'an, mulai dari arah atas, bawah sampai bersemayamnya Allah di 'ars, wajah, tangan, cinta dan benci, begitu pula dengan apa yang ada dalam hadits Nabi Mubammad dengan teks dhabir tanpa ta'minl. $\$ 30$

Sebagai gambaran, penulis akan membawakan contoh penafsiran dari Muhammad bin Shalih Al-Utsaimin, salah satu tokoh sekaligus guru dari Yazid bin Abdul Qadir Jawas, salah satu tokoh Islam Salafi di Indonesia yang cukup masyhur dalam menanggapi surah al-Maidah ayat ke 64, yaitu :

$$
\text { الفاشرة : أنها اثنتان لإنعة : إثبات اليدين الله عز و جل، لقوله : (بل يداه مبسوطتان). الفائدة }
$$

"Faidah kesembilan dari ayat ke 64 surat al-Maidah adalah : menetapkan kedua tangan pada Allah Azza Wa Jall, sebagaimana firmannya (بل يداه مبسوطنان), dan faidah kesepuluh : Bahwa tangan itu ada dua, tanpa ada penambahan juga pengurangan."

Disini Nampak bahwa Utsaimin menetapkan bahwa Allah memiliki tangan yang tidak terbelenggu, ia juga meyakini bahwa tangan Allah itu ada dua, tanpa ada pengurangan dan tanpa ada penambahan.

\footnotetext{
${ }^{28}$ Muhammad Abu Zahrah, 181.

29 Muhammad bin Salih al-Utsaimin, Sharah Taqrïb Al-Tarmudhiyyah (Saudi: Lembaga Informasi Syaikh Muhammad bin Ṣalih al-Utsaimin, t.th.). 73.

${ }^{30}$ Muhammad Abu Zahrah, 183.

31 Muhammad bin Shalih al-Uthaimin, Tafsir Surat Al-Māidah, Juz 2 (Dār Ibnu al-Jauzi, 2003). 115
} 


\section{Biografi dan Sketsa Tafsir Aswaja NU}

Nahdlatul 'Ulama' ${ }^{32}$ (Kebangkitan 'Ulama) atau yang juga disingkat NU, merupakan sebuah organisasi Islam terbesar di Indonesia. Organisasi ini berdiri pada 31 Januari 1926 yang bergerak dalam bidang keagamaan juga pendidikan, sosial dan ekonomi. ${ }^{33}$ Untuk menegaskan prinsip dasar organisasi ini, maka K.H. Hasyim Asy'ari merumuskan kitab Qanun Asasi (prinsip dasar), kemudian juga merumuskan kitab I'tiqad Ablussunnah Wal-Jamäab. Kedua kitab tersebut kemudian diejawantahkan dalam khittah NU, yang dijadikan sebagai dasar dan rujukan warga NU dalam berpikir dan bertindak dalam bidang sosial, keagamaan dan politik.

Sebagaimana telah ditegaskan dalam Khittah $^{34} \mathrm{NU}$ pada Muktamar NU ke 27 point a, yaitu : Dibidang Akidah, Nahdlatul Ulama mengikuti ablussunnah wal-jamäah yang dipelopori oleh Imam Abu al-Hasan al-Asy'ari dan Imam al-Maturidi. Oleh karena itu,

32 Dalam literatur Bahasa Arab, susunan kata ini tertulis نهضة yang memiliki arti kebangkitan, melawan dan gerakan, serta علماء yang merupakan jama' taksir dari kata عالم yang memiliki makna Cendekiawan atau orang yang memiliki ilmu. Nama "Nahdlatul Ulama" diusulkan oleh KH. Mas Alwi bin Abdul Azis dari Surabaya (sepupu KH. Mas Mansur, tokoh NU yang kemudian menyeberang ke Muhammadiyah karena berbeda haluan dan pandangan keagamaan). Pengertian nama ini kurang lebih "gerakan serentak para ulama dalam suatu pengarahan", atau "gerakan bersama-sama yang terorganisir". Sebenarnya, sebelum bernama Nahdlatul Ulama, sempat muncul nama „Nuhudlul Ulama“ yang diusulkan oleh KH. Abdul Hamid dari Sedayu, Gresik, dengan argumen bahwa para ulama mulai bersiap-siap untuk bangkit melalui wadah formal tersebut. Pendapat ini disanggah keras oleh Mas Alwi, dengan alasan bahwa kebangkitan ulama tidak lagi mulai atau akan bangkit, tetapi kebangkitan itu sudah berlangsung sejak lama dan bahkan sudah bergerak jauh sebelum adanya tanda-tanda akan terbentuknya komite Hijaz, hanya saja belum terorganisir. Karena itu, menurut Mas Alwi, nama yang tepat adalah „Nahdlatul Ulama" bukan „Nuhudlul Ulama". Pendapat ini yang kemudian diterima secara aklamasi oleh peserta pertemuan (musyawarah). Adapun lambang Nahdlatul Ulama, berupa bola dunia, diciptakan oleh KH. Ridwan Abdulloh dari Surabaya. Lihat : Panitia Harlah NU Ke-40, "Sedjarah Ringkas Nabdlatul Ulama" Dalam Chairul Anam, Pertumbuban Dan Perkembangan NU (Surabaya: Duta Aksara Mulia, 2010). 4

${ }^{33}$ http://illsionst.blogspot.com/2011/06/sejarah-dan-perkembangan-nu.html. Di akses tanggal 23-April-2021.

34 Kata khittah berasal dari akar kata khaththa, yang bermakna menulis dan merencanakan. Kata khiththah kemudian bermakna garis dan thariqah (jalan)". 
sebagaimana tokoh panutan Aswaja NU dalam ranah akidah, yakni ; Imam Abul Hasan Al-Asy'ari dan Imam Abu Mansur Al-Maturidi, NU juga memilih sikap moderat sebagaimana yang disampaikan oleh al-Asy'ari dan para penganutnya (al-Asy'ariyab atau alAsya'irah), yakni tidak lepas dari cara al-Asy'ari dalam pengambilan dalil (istidla). Al-Asy'ari menggunakan dua dalil sekaligus (naqli dan aqli) dalam berargumentasi mengenai persoalan aqidah. Ia tidak hanya menggunakan ayat-ayat al-Qur'an dan hadis dalam menetapkan sifat-sifat Allah, para rasul-Nya, hari kiamat, malaikat, hisab serta nikmat surga dan siksa neraka, namun juga memerankan fungsi akal dan dalil-dalil rasional dalam membuktikan kebenaran dalil naqli tersebut. ${ }^{35}$

Menurut NU, ada dua metode untuk menyikapi ayat-ayat mutasyabihat yang keduanya sama-sama benar: Pertama, metode tafwìd (disebut sebagian ulama dengan istilah ta'mī ijmälì/takwil secara global). Kedua, metode ta'mīl (disebut sebagian ulama dengan istilah ta'mil tafsili /takwil secara terperinci). Metode ini digunakan oleh sebagian besar ulama khalaf (ulama yang hidup setelah tiga abad pertama Hijriah). ${ }^{36}$ Begitupula pendapat ulama Asy'ariyah dalam menganggapi ayat mutashabihāt. Sesungguhnya ini adalah masalah, ijtihädiyyah, yakni soal ta'mil dan tafwìd beserta tanzīh (menyucikan Allah dari sifat yang tak layak). Sesungguhnya musibah besar dan petaka yang parah adalah meyakini makna lahiriyah lalu meyakini bahwa itulah yang dimaksud dan bahwa itu tak mustahil bagi Allah. Itu adalah keyakinan para Mujassimah, yaitu para penyembah berhala." ${ }^{37}$ Dari sini, hemat penulis, yang sering dijadikan metode penafsiran oleh NU adalah antara dua kemungkinan, yakni tafwìd atau ta'mill, hal itu sebagaimana yang dilakukan oleh penutan mereka dalam bidang akidah, yakni Imam Asy'ari atau pengikutnya.

\footnotetext{
${ }^{35}$ Ahmad Atabik, "Corak tafsir aqidah", 215.

36 Dikutip dari https://islam.nu.or.id/post/read/117330/metode-memaknaiayat-mutasyabihat-atau-belum-jelas-maknanya , diakes pada 06-05-2021.

37 Diakses dari https://islam.nu.or.id/post/read/94919/dua-sikap-ahlussunnahtentang-sifat-khabariyah-allah pada 06-05-2021
} 


\section{Pendapat Islam Salafi Tentang Ayat Mutashābihāt fì al- Shifāt}

\section{Ayat-ayat yang berkaitan dengan istiwa'.}

Istiwa (bersemayam) merupakan sifat fi'liyah (perbuatan) bagi Allah Ta'ala. Ablussunnah wal-jamäah menetapkannya sesuai dengan makna yang layak bagi-Nya, tanpa dirubah (tabrif) maknanya, sebagaimana yang dilakukan oleh ahli ta'wil yang merubah maknanya menjadi 'menguasai' (istii'la)! Tidak juga diserupakan dengan bersemayamnya makhluk, karena sesungguhnya Allah tidak ada satupun yang menyerupai dzat-Nya dan tidak ada satupun yang menyerupai sifatnya. ${ }^{38}$

Menurut Abu Bakr Anas Burhanuddin Penerjemahan kata istawa (إسْنَوَى) dengan “bersemayam” perlu di tinjau ulang, karena dalam kamus bahasa Indonesia disebutkan bahwa bersemayam berarti duduk, tinggal, berkediaman. Ia lebih cenderung memaknainya dengan cukup Allah berada di atas. ${ }^{39}$ Menurut Islam Salafi, keberadaan Allah diatas sudah sangat familiar dalam bahasa sehari-hari, yakni dengan kata-kata "Kita serabkan pada Yang di Atas", "Kalau Yang di Atas telah berkehendak", dan lain-lain yang semisal, atau kita berdoa yang selalu menengadahkan tangan keatas ${ }^{41}$ sudah sering kita dengarkan atau bahkan juga kita lakukan bukankah itu sebuah pengakuan bahwa Allah berada di atas?.

Salafi meyakini bahwa Allah istiwa' (berada di atas) 'arsy (singgasana) Nya. Dan 'Arsy, ia merupakan ciptaan Allah yang paling besar, ia dibawa oleh beberapa malaikat sebagaimana dalam

\footnotetext{
${ }^{38}$ Diakses dari https://islamqa.info/id/answers/145804/penjelasan-tentangsifat-istiwa-betis-wajah-adalah-milik-allah-apakah-tubuh-termasuk-sifat-allahtaala? fbclid=IwAR0ssHeOgBr9lvFHMHL5FwlidDvS9YfebDTKMdQ5QkCm 3pSOqmNFv-MiVC4 pada 23-April-2021.

${ }^{39}$ Diakses dari https://muslim.or.id/56-sifat-istiwa-allah-di-atas-arsy.html pada 23-April-2021.

${ }^{40}$ Dikutip dari https://firanda.com/1829-antara-ust-abdul-somad-ma-mutazilah-imam-abul-hasan-al-asy-ary-pro-nabi-sahabat-serta-imam-imamsalaf.html ,, di akses pada 23-April-2021.

${ }^{41}$ Dikutip dari https://www.youtube.com/watch?v=F7ziQtE5HzI pada 23 April-2021.
} 
surat al-Haqqah : 17 dan Ghafir : $7^{42}$ sebagaimana ia disifati oleh Allah dengan Karim (mulia), dan 'Adhim (besar). ${ }^{43}$ Allâh Azza wa Jalla telah banyak memberitakan bahwa diri-Nya bersemayam di dalam al-Qur'an, diantaranya adalah Q.S Thaha 20:5

Mengenai bersemayam-nya Allah sebagaimana yang dikatakan oleh Salafi, mereka juga mengatakan bahwa kursi adalah tempat kedua kaki Allah di atas langit, sebagaimana mereka mengatakan : "Kursi adalah tempat diletakkan kedua kaki Allah, sedangkan 'arsy tidak bisa diperkirakan ukurannya". ${ }^{44}$ Hal ini muncul sesuai firman Allah pada Q.S al-Baqarah 2:255

\section{Ayat-ayat yang Berkaitan dengan Yad.}

Salafi meyakini bahwa Allah memiliki dua tangan, Hal ini berdasarkan firman Allah 'azza wa jalla pada Q.S Al-Maidah 3:64 "bal yadāhu mubsütatān (Tidak demikian), tetapi kedua tangan Allah terbuka)" atau pada Q.S Shaad 38:75 "mà mana'aka an tasjuda limā kholaqtu biyadayya (Hai iblis, apakah yang menghalangi kamu sujud kepada yang telah Ku-ciptakan dengan kedua tangan-Ku)". Dengan ayat-ayat yang berkonotasi seperti diatas, secara spontanitas Islam Salafi akan memaknai sesuai dengan makna bahasa arab lumrah, yakni tangan, dengan tanpa perubahan makna. Berbicara tentang tangan, hal yang selanjutnya layak untuk dibahas adalah apakah kedua tangan tersebut terdiri dari tangan kanan dan kiri atau selainnya, Salafi mengutip beberapa pendapat, diantaranya adalah $^{45}$ :

\section{Dua tangan kanan}

Dalam hal ini, mereka mengambil dalil dari sabda Rasulullah saw :

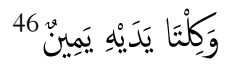

\footnotetext{
42Dikutip dari https://muslim.or.id/56-sifat-istiwa-allah-di-atas-arsy.html pada 23-April-2021.

${ }^{43}$ Dikutip dari https://www.youtube.com/watch?v=QpuJ15XZ Ak pada 23April-2021.

${ }^{44}$ Dikutip dari https://muslim.or.id/32468-apa-itu-kursi-allah.html pada 23April-2021.

45Dikutip dari http://asysyariah.com/dua-tangan-allah/ pada 23-April-2021.

46 Imām Muslim, Shahīh Muslim, Juz 3 (Beirut: Dar Ihya al-Turats al-'Arabī, t.th.). 1458 .
} 
"Dan kedua tangan Allah itu kanan."

\section{Tangan kanan dan kiri}

Pendapat ini juga didasari dengan sabda Rasulullah saw, yang artinya:

"Allah 'azza wa jalla melipat langit-langit pada hari kiamat lalu mengambilnya dengan tangan kanan-Nya seraya berkata, "Akulah Sang Raja, di manakah para diktator? Di manakah orang-orang yang sombong?,'Lalu Allah melipat bumi-bumi dengan tangan kiri-Nya seraya berkata, "Akulah Sang Raja, di manakah para diktator? Di manakah orang-orang yang sombong?." 47

Berakar dari kata "Yad (tangan)" dalam hadits tersebut berindikasi bahwa Allah memiliki dua tangan. Tangan kanan digunakan untuk mengambil lipatan langit dan tangan kiri digunakan untuk melipat bumi. Pendapat ini agaknya sama dengan apa yang dikatakan Utsaimin, sebagaimana sudah penulis kutip dibagian biografi Islam Salafi.

\section{Tangan yang lain}

Pendapat ini juga berpijak pada sabda Nabi Muhammad saw, yakni:

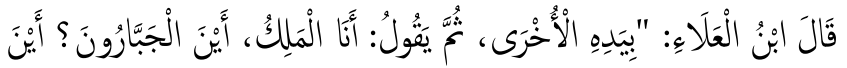

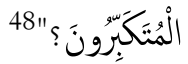

"Ibnul 'Ala', salah seorang perawi hadits mengatakan, "dengan tangan- Nya yang lain, lalu Allah 'azza wa jalla berkata, 'Akulah Sang Raja, di manakah para diktator? Di manakah orang-orang yang sombong?.”

Selain itu, mereka juga mengatakan bahwa Allah memiliki jari-jemari, telapak tangan dan lengan yang kuat. ${ }^{49}$

\footnotetext{
${ }^{47}$ Imam Muslim, Juz 4, 2148

48 Abu Daud, Sunan Abu Daud, Juz 4 (Beirut: al-Maktabah al-'Isriyah, n.d.). 234.
} 


\section{Ayat-ayat yang berkaitan dengan wajah.}

Konsep pemikiran Salafi dalam memaknai wajah adalah meyakini bahwa Allah memiliki wajah secara hakiki ${ }^{50}$ dengan tanpa tanpa ta'wil, tasybïh ${ }^{51}$, ta'thi $i^{2}$ dan takyif ${ }^{3}$, bahkan kenikmatan yang paling agung dan tinggi, melebihi kenikmatan di surga adalah memandang wajah Allah yang maha mulia. Karena inilah "tambahan" yang paling agung melebihi semua kenikmatan yang Allah berikan kepada para penghuni surga. Mereka berhak mendapatkan kenikmatan tersebut bukan semata-mata karena amal perbuatan mereka, tetapi karena karunia dan rahmat Allah. ${ }^{54}$ Sebagaimana firmannya pada Q.S al-Qiyamah 75:22-23.

Setelah berbicara tentang makna wajah, pembahasan ini akan merembet pada surat al-Qashash, yakni :

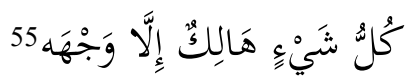

"Segala sesuatu itu akan musnah, kecuali Wajah Allah".

Saat mereka disodorkan ayat ini dan disangkut pautkan dengan ayat sifat yang lain akan mengarah pada tidak adanya sifat Allah selain wajahnya, dalam menjawab ini Salafi berkomentar :

1. Ini adalah mahfüm mukhälafah, mahfüm ini berlaku jika tidak bertentangan dengan dalil yang lain. Berdasarkan kaidah ushul fiqih yang ada kita tidak boleh menyimpangkan makna kata wajah kepada makna lainnya. Inilah hukum asalnya. Selain itu tidak ada dalil sah lagi tegas yang mendukungnya. Selain itu

\footnotetext{
${ }^{49}$ Selengkapnya bisa dibaca dalam https://salafy.or.id/blog/2005/02/25/mengimani-akan-sifat-kedua-tanganallah-taala/ .

${ }^{50}$ Mereka berdalih bahwa semua hukum asal suatu kata didalam ayat maupun hadits harus dimaknai dengan makna hakiki, tidak boleh menyimpangkan makna hakiki kepada makna lainnya kecuali apabila ada dalil yang tepat (Baca : https://muslim.or.id/64-apakah-allah-memiliki-wajah.html, diakses pada 23April-2021.

${ }^{51}$ Menyamakan Allah dengan mahluknya.

${ }^{52}$ Menolak beberapa firman Allah dengan memalingkan maknanya.

${ }^{53}$ Membagaimanakan apa yang sudah disebutkan oleh Allah pada dirinya

${ }^{54}$ Dikutip dari https://khotbahjumat.com/3772-memandang-wajah-allahanugerah-terbesar-di-surga.html pada 23-April-2021.

${ }^{55}$ Q.S al-Qashash 28:88.
}

167 | Mushaf: Jurnal Tafsir Berwawasan Keindonesiaan Volume 1. Nomor 2, Juni 2021. 
penafsiran semacam itu juga bertentangan dengan metode penafsiran ulama salaf.

2. Kalau kalian beralasan bahwa apabila kita memaknai wajah Allah sebagai wajah sebenarnya kemudian jika makna itu diterapkan pada ayat di atas maka itu artinya tangan Allah juga ikut hancur maka sungguh ini adalah pemahaman yang sangat keliru!, ini juga akan bertentangan ketika kita melihat ayat lain, semisal : "Allah adalah pencipta segala sesuatu" Saya bertanya: Apakah Allah juga menciptakan diri-Nya sendiri? Tentu tidak !!Bukankah kata 'segala sesuatu' itu juga mencakup Allah, lalu mengapa kalian keluarkan Allah dari makna ayat ini ?!.

3. Taruhlah makna kata wajah dalam ayat kullu syai'in haalikun illa wajhah adalah bukan wajah yang sebenarnya lalu bagaimana kalian akan memaknai hadits : Nabi shallallahu 'alaihi wa sallam berdoa: "Wa as'aluka ladzdzatan nazhari ila wajbika wasy syanqa ila liqaa'ika" (Dan aku memohon kenikmatan memandang wajah$\mathrm{Mu}$ serta kerinduan untuk menemui-Mu?). ${ }^{56}$

\section{Ayat-ayat yang berkaitan dengan a'yun (mata).}

Dalam memaknai a'yun (mata), Salafi memilih untuk tetap konsisten tidak merunah apa yang sudah Allah tetapkan pada dirinya, sebagaimana firmannya yang mencantumkan kata "A'yun (mata)", seperti Q.S al-Qamar 54:14. Adapun beberapa dalil yang dikutip oleh mereka diantaranya adalah perkataan Imam As'ary dalam kitabnya al-Ibānah 'An Ushuli Ad-Diyanah, yakni :

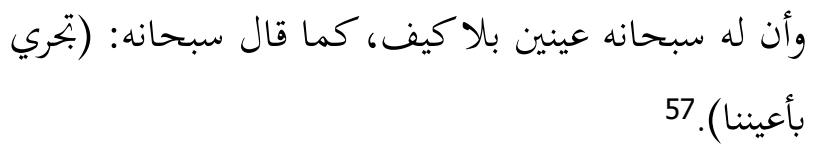

"Bahwasannya Allah subhaanahu wa ta'ala mempunyai dua mata tanpa perlu ditanyakan bagaimananya (kaifiyahnya), sebagaimana Allah subhaanahu wa ta'ala berfirman :

${ }^{56}$ Dikutip dari https://www.facebook.com/groups/165106884207146/permalink/272616116 $\underline{789555}$ pada 22-Juli-2019.

${ }^{57}$ Dikutip dari http://abul-jauzaa.blogspot.com/2011/07/sifat-mata-bagiallah.html pada 22-Juli-2019.

168 | Mushaf: Jurnal Tafsir Berwawasan Keindonesiaan Volume 1. Nomor 2, Juni 2021. 
'Yang berlayar dengan pemeliharaan (pengawasan mata) Kami” (QS. Al-Qamar : 14)".

\section{Pendapat Aswaja NU Tentang Ayat Mutashābihat fi as-Ṣifāt Ayat-ayat yang berkaitan dengan istiwa'.}

Dalam menanggapi ayat mutashäbihät ini, Nahdlatul Ulama' yang konsep berfikirnya dalam bidang akidah mengikuti Abu al-Hasan al-As'ary, menandakan dan membuktikan bahwa NU hanyalah organisasi yang sepenuhnya ber-madzhab pada Ulama' yang memang dititipkan ilmu oleh Allah, oleh karenanya mereka cenderung mengutip beberapa pendapat tentang makna istawa, yaitu :

1. Golongan ahli tafwid akan memilih diam tak membahas apa yang dimaksud istawa tersebut. Mereka akan menolak semua arti fisik dari kata istawa seperti: duduk bersemayam, berdiam, melayang di atas atau makna fisikal lainnya sebab itu mustahil bagi Allah. Mereka juga akan menolak arti metaforis, seperti makna menguasai, menundukkan dan sebagainya sebab bagi mereka makna ini hanya praduga semata. Mereka lebih suka tak menentukan makna apa pun selain membaca ulang dengan redaksi asalnya (imrâr). Kalaupungolongan ini memberi makna, maka mereka hanya akan menjelaskan bahwa istawa adalah sebuah tindakan Allah yang Dia namai sebagai istawa dan hanya Allah yang tahu bagaimana tindakan tersebut sebenarnya.

2. Adapun golongan ahli ta'wil akan memilih mengartikan kata istawa itu dengan makna metaforis, misalnya menguasai mutlak (qabhara) sesuai sifat Allah yang memangalQabhär (Maha-Menguasai secara mutlak tanpa perlu memaksa atau menaklukkan). Dalam makna ini, ayat itu bermakna Allah menguasai Arasy secara mutlak, apalagi makhluk yang lebih kecil dari itu. Sebagian lagi memaknai istawa sebagai mengurus/ memelihara (dabbara) sesuai dengan sifat Allah yang memang alMudabbir (Maha-Memelihara). Dalam makna ini, ayat tersebut bermakna Allah telah mengurus Arasy, makhluk terbesar di dunia, apalagi hanya yang lebih kecil. ${ }^{58}$

${ }^{58}$ Dikutip dari https://islam.nu.or.id/post/read/94919/dua-sikap-ahlussunnahtentang-sifat-khabariyah-allah pada 23-April-2021. 
Disamping sikap NU yang memilih jalan sebagaimana di atas, NU juga mengecam saat lafadz istawa diterjemahkan "bersemayam", sebab bersemayam sendiri dalam kamus bahasa indonesia memiliki arti duduk, berdiam atau tinggal di atas Arasy. Kesemua makna ini tanpa diragukan adalah makna jismiyah yang seharusnya dibuang jauh-a dari Allah sebab tak layak bagi kesucian-Nya. ${ }^{59}$

Maka pendapat yang pantas untuk penulis cantumkan adalah pendapat Sayyid Syeif Alwi, salah satu generasi muda NU : Allah ada namun tidak bertempat ${ }^{60}$, jika memang Allah bertempat bagaimana dengan ayat وَهُهَ مَعَكُمْ أَيْنَ مَا كُنْنُُْم (Dia Allah bersama kamu di mana saja kamu berada), yakni maksudnya ketika beberapa orang berkumpul maka Allah ada disitu, lalu jika beberapa kelompok berkumpul apakah Allah ada banyak? Tidak!, Allah hanya satu. Lalu mengapa Allah menyebut 'arsy? Karna ia adalah mahluk ciptaan Allah yang paling besar yang meliputi langit dan bumi, maka dari itu menurut Syeif Alwi sebagaimana juga dikatakan oleh beberapa Ulama ${ }^{51}$ makna yang pas adalah "menguasai dan penaklukan", yakni dengan metode ta'minl.62

\section{Ayat-ayat yang berkaitan dengan yad (tangan).}

Kata al-yad "اليد" dalam bahasa Arab memiliki makna yang sangat banyak, di antaranya dalam makna an-Ni'mah wa al-Ihsân " النعمة والإحسان", artinya; "Karunia (nikmat) dan kebaikan". Adapun makna perkataan orang-orang Yahudi dalam firman Allah: Yadullâh Maghlûlah "يد الله مغلولة" adalah dalam makna " محبوسة عن النفقة", artinya menurut orang-orang Yahudi Allah tidak

\footnotetext{
${ }^{59}$ Dikutip dari https://islam.nu.or.id/post/read/94918/bolehkah-mengatakanallah-bersemayam-di-atas-arasy pada 23-April-2021.

${ }^{60} \mathrm{Hal}$ ini juga diperkuat dengan dalil yang sudah terkumpul dalam aplikasi yang berfaham NU, diakses dari http://www.piss-ktb.com/2013/02/2222-kajiantauhid-allah-ada-tanpa.html pada 23-April-2021.

${ }^{61}$ Disebutkan dalam http://www.piss-ktb.com/2012/03/f0107-mentakwilistawa-dengan-istaula.html bahwa ada sekitar 74 Ulama' yang berpendapat demikian. Diakses pada 23-April-2021.

${ }^{62}$ Dikutip dari https://www.youtube.com/watch?v=874tWRRMO8s pada 23April-2021.
} 
memberikan karunia dan nikmat, (bukan arti ayat tersebut bahwa Allah memiliki tangan yang terbelenggu).

Makna lainnya, kata al-yad dalam pengertian "القوة" ; artinya "Kekuatan atau kekuasaan". Orang-orang Arab biasa berkata:" له بهذا الأمر يد", (Orang itu memiliki kekuatan (kekuasaan) dalam urusan ini). Firman Allah: "بل يداه مبسوطتان"; yang dimaksud dalam pengertian ini, artinya bahwa nikmat dan kekuasaan Allah sangat luas (bukan artinya bahwa Allah memiliki dua tangan yang sangat lebar).

Demikian pula firman Allah tentang penciptaan Nabi Adam: "لما خلقت بيدي"; juga dalam pengertian bahwa Allah menciptakan Nabi Adam dengan kekuasaan-Nya dan dengan karunia dari-Nya. Kemudian pula diriwayatkan dari Imam al-Hasan dalam tafsir firman Allah: "يد الله فوق أيديهم"; beliau berkata: "Kata "يد" di sini yang dimaksud adalah karunia dan nikmat Allah". Inilah penafsiran-panafsiran dari para Ulama Abli Tahqiq. ${ }^{63}$

Said Aqil Siradj, Ketua PBNU 2010-sekarang pernah menyampaikan bagaimana sikap NU ketika bertemu dengan ayat "يد الله فوق أيديهخ، adalah menterjemahkan dengan "kekuasaan". ${ }^{64}$

\section{Ayat-ayat yang berkaitan dengan dengan wajah.}

Mengenai makna wajbullah atau ayat yang terdapat kata wajhu yang kemudian disandarkan pada diri Allah, Tgk Alizar Usman, ketua pengurus besar naddlatul ulama (PWNU) Aceh ini mengutip pendapat Fakhruddin ar-Razi, bahwa pengertian (wajhullah) pada ayat di atas mempunyai kemungkinan makna sebagai berikut:

1. Bermakna arah yang dihadap pada waktu shalat, yakni qiblat. Diidhafah wahj kepada Allah adalah seperti idhafah bait kepada Allah (baitullah) dan naaqah (unta) kepada Allah (naaqatullah). Idhafah seperti ini, maksudnya adalah idhafaf bil-khlaq walijaad 'ala sabilil tasyrif (menyandarkan ciptaannya kepada Allah untuk memuliakannya).

\footnotetext{
${ }^{63}$ Dikutip dari http://www.piss-ktb.com/2012/02/337-pengertian-tangan-allahswt.html?fbclid=IwAR25wcMgiBKZZOzCVWrge3dRCSqm2A9p9zSXTTfW0y6EWqdnGwoexee-64 pada 23-April-2021. ${ }^{64}$ https://www.youtube.com/watch?v=2fKyrzQdkPY
} 
2. Bermakna niat dan qashad. Ayat lain yang sama dengan pengertian ini adalah firman Allah, Q.S. al-An'am : 79.

3. Bermakna keridhaan Allah. Ayat lain yang sama dengan pengertian ini adalah firman Allah pada Q.S. al-Insan : 9.

4. Bermakna karunia Allah. Ayat lain yang sama dengan pengertian ini adalah firman Allah pada Q.S. al-Qashas :88.

Berdasarkan keterangan ahli tafsir diatas, tidaklah tepat pengertian (wajhullah) pada ayat Q.S. al-Baqarah : 115 di atas ditafsirkan bermakna dzat Allah, lebih-lebih lagi kalau ditafsirkan bahwa pada benda yang dihadap itu menyatu dengan zat Allah. na'uzubillah min dzalik. Demikian juga, kalau ayat tersebut dimaknai dengan makna wajah Allah, karena hal itu sama halnya dengan menetapkan suatu yang berjisim pada Allah Ta'ala. ${ }^{65}$ Sedangkan munurut Said Aqil Siradj makna wajah itu adalah wujudnya tuhan, yakni perpaduan antara dalil naqli dan 'aqli. ${ }^{66}$

\section{Ayat-ayat yang Berkaitan Dengan A'yun (mata).}

Sebagaimna yang telah lalu, bahwa NU sendiri menolak pada pemaknaan teks ayat secara dhahiriyah, apapun ayat yang berkonotasi jismiyah (memiliki organ) akan di ta'wil dengan penta'wül-an yang sesuai. Dalam tema ini penulis merasa kesulitan dalam mencari pernyataan sikap NU terhadap ayat yang menyinggung lafadz a'yun, hanya saja, agaknya NU memilih untuk tetap konsisten pada pendirian awal, sebagaimana pernah diungkapkan-nya sebagai berikut.

$$
\begin{aligned}
& \text { وقال أحمد: أحاديث الصفات تمر كما جاءت من غير بحث على معانيها، وتخالف }
\end{aligned}
$$

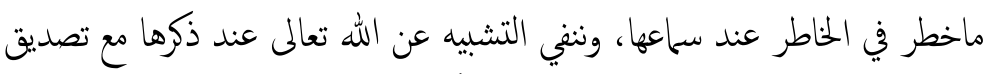

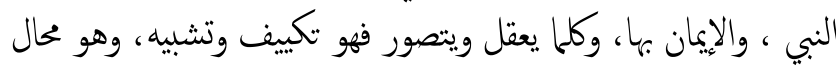

${ }^{65}$ Dikutip dari https://al-waliwisy.blogspot.com/2014/11/arti-wajah-allahdalam-al-quran.html? $\mathrm{m}=1 \&$ fbclid=IwAR1v2J3-

ZfEGwuFadzkiOZdXyqmOgPVp1 wRD9ArNIjORbkCGjzuMjR-L-U pada 23-April-2021.

${ }^{60}$ Dikutip dari https://www.youtube.com/watch?v=2fKyrzQdkPY 23-April2021. 
"Imam Ahmad berkata: Hadits-hadits sifat harus dibaca ulang seperti sedia kala tanpa dibahas makna-maknanya. Ia berbeda dengan apa yang terbesit dalam hati seseorang ketika mendengarnya. Dan, kami menafikan penyerupaan dengan Allah ketika Allah menyebutkannya serta membenarnya [ucapan] Nabi dan mengimaninya. Setiap kali ia dipahami dan tergambar di benak, maka itulah membagaimanakan (takyîf) dan menyerupakan (tasybīh). Itu adalah mustahil." (Ibnu Hamdan al-Hanbali, Nihâyat alMubtadi'în, halaman 33).

Dalam kaidah ini, yang disebut penyerupaan adalah segala gambaran yang muncul di kepala dan dapat dipahami. Ketika misalnya membaca kata yadullah kemudian tergambar di benak kita adanya organ tubuh Allah yang dipakai untuk mengerjakan macam-macam hal, maka itulah tasybīh. Ketika membaca kata nuzûl lalu tergambar di benak bahwa Allah bergerak turun dari atas ke bawah, maka itulah tasybīh. Ketika membaca kata "istiwâ"' lalu tergambar dalam benak bahwa Allah bertempat di atas Arasy, maka itulah tasybih. Dan demikian seterusnya untuk kata-kata lain, apabila kata yang dinisbatkan pada Allah tersebut dipahami seperti makna yang di kamus-kamus, maka itulah tasybīb. Mau diiringi dengan penjelasan "seperti makhluk" atau "tak seperti makhluk", sama sekali tak berarti dalam kaidah ini sebab yang menjadi intinya adalah penetapan makna seperti yang dipahami manusia. ${ }^{67}$

\section{Analisis Persamaan dan Perbedaan}

Antara Salafi yang berkembang pesat di Indonesia ahir-ahir ini dan Aswaja NU sebenarnya memiliki persamaan secara garis besar, yakni bagaimanapun output yang keluar dari keduanya, mereka sama-sama memiliki tujuan tidak menyamakan Allah Swt dengan mahluknya. Hanya saja, hal itu jika dipandang dari diri Salafi yang sudah biasa mengatakan Allah punya tangan, wajah, kaki dan sebagainya nampak bertentangan, bagaimana mungkin seseorang yang sudah mengatakan bahwa allah punya tangan, wajah, mata dan lain-lain masih bisa dikatakan bahwa ia tidak menyerupakan Allah dengan mahluknya?. Mengatakan Allah punya organ tubuh,

${ }^{67}$ Dikutip dari https://islam.nu.or.id/post/read/95849/kapan-kita-dianggapmenyerupakan-allah-dengan-makhluk pada 23-April-2021. 
dalam kebanyakan literature disebut Mujassimab (orang yang mengatakan Allah Swt. memiliki anggota tubuh), hal ini sebagaimana kaidah dari Imam Ahmad. ${ }^{68}$

Imam Ahmad mengatakan bahwa akan termasuk suatu penyerupaan ketika kita sudah menggambarkan gambaran yang muncul di kepala dan dapat dipahami. Ketika misalnya membaca kata yadullah kemudian tergambar di benak kita adanya tangan Allah yang dipakai untuk mengerjakan macam-macam hal, maka itulah tasybîh. Ketika membaca kata nu₹ul (turun) lalu tergambar di benak bahwa Allah bergerak turun dari atas ke bawah, maka itulah tasybîh. Ketika membaca kata (istiwa) lalu tergambar dalam benak bahwa Allah bertempat di atas Arasy, maka itulah tasybîh. Dan demikian seterusnya untuk kata-kata lain, apabila kata yang dinisbatkan pada Allah tersebut dipahami seperti makna yang di kamus-kamus, maka itulah tasybîh. Mau diiringi dengan penjelasan "seperti makhluk" atau "tak seperti makhluk", sama sekali tak berarti dalam kaidah ini sebab yang menjadi intinya adalah penetapan makna seperti yang dipahami manusia. Oleh karenanya, sekalipun mereka mengatakan "Allah punya tangan namun tangannya berbeda dengan tangan mahluknya" mereka akan tetap dikatakan mujassimah atau menyamakan allah dengan mahluknya.

Sering penulis temukan, mereka sering menggunakan perkataan Ibnu Abbas dalam hal ini, yakni : لاستواء معلوم، والكيف

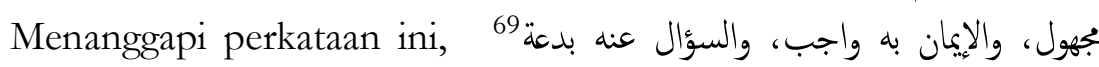
Ulama’ salaf berkata : Bahwa yang dimaksud dengan maklumnya makna istiwa ialah sesuai dengan bahasa arab secara umum, yakni berarti tinggi, dan terangkat. ${ }^{70}$, yang menjadi titik kutipan mereka adalah 'Makna istiwa' itu sudah maklum (diketahui), dan bagaimananya itu tidak diketabui", bagi penulis, jikalau mereka memang ingin mengutip perkataan ini, mengapa tidak secara sempurna?, bukankah arah perkataan ini justru mengarah pada tafwid \{

\footnotetext{
${ }^{68}$ Dikutip dari https://islam.nu.or.id/post/read/95849/kapan-kita-dianggapmenyerupakan-allah-dengan-makhluk pada 23-April-2021.

${ }^{69}$ Nashir bin Abdul Karim Al-Aql, Islamiyyah La Wababiyyah, Juz 1 (Eropa: Dar Al-Kunuz Asbiliya, n.d.). 78

70 Imam Al-Dhahabi, Al-'Arsy Li Al-Drahabi, Juz 1 (Madinah: Dekan Universitas Islam, 2003). 189.
} 
(menyerahkan maksudnya hanya pada Allah)?, mengapa mereka harus sampai menyingkap bahwa istiwa' itu bermakna bersemayam, atau yadullah itu bermakna tangan? bukankah hal ini jika dikaitkan kembali dengan perkataan Imam Ahmad di atas justru akan mengarah pada tajsim (mengatakan Allah punya organ tubuh)?

Hal yang paling aneh adalah; mereka selalu saja mengatakan bahwa mereka mengikuti ulama salaf, dan mereka mengatakan bahwa tidak ada satupun Ulama' salaf yang men- ta'wil ayat alQur'an khususnya ayat mutashäbihät, lalu bagaimana dengan perkataan Imam Syafi'i (W $204 \mathrm{H}$ ) dalam karyanya, Fiqhul Akbar, ${ }^{71}$ Imam Syafi'I mengatakan bahwa Allah ada dan tidak memiliki tempat, keberadaan Allah adalah sama seperti zaman azaliyah, sebelum ia menciptakan tempat, mengatakan Allah memiliki tempat berarti mengatakan Allah terikat oada sesuatu, padahal itu adalah mahluk.

Tentang makna يَ يُد yang oleh Salafi dimaknai tangan, "Sebagai kemuliaan Nabi Adam, Allah menciptakannya dengan kedua tangannya sendiri", seperti itu kiranya salah satu hujjah mereka. Bagi penulis, dengan tidak mengenyampingkan beberapa ayat yang dan keagungan-Nya, alasan seperti itu tak patut dijadikan hujjah, sebab Allah sangat mulia, ia tidak lagi butuh dengan semua peralatan dalam semua perbuatan-Nya. Selain makna istawa di atas, mereka juga mengatakan bahwa tidak ada Ulama' Salaf yang men- ta'wil tentang ayat yadullah. Al-Baghawi pernah menuliskan dalam tafsirnya, mengutip perkataan Ibnu Abbas dan lainnya, ia menuliskan bahwa makna dari "Yadullah Fauqo Aydibim" menurut Ibnu Abbas Allah diatas mereka dalam hal mencukupi atas kebaikan yang telah Allah janjikan. As-Sadd berkata : mereka menjadikan tangan Rosulullah dan membaiatnya, sedangkan yad Allah di atas tangan mereka dalam masalah pembaiatan. Al-Kalbi berkata : Ni'mat Allah dengan hidayahnya di atas segala sesuatu yang ia jadikan sebagai pembaiatan. ${ }^{72}$

Jika memang Firanda Andirja mengatakan Asha'irah itu sesat karena menakwil sifat-sifat Allah, padahal ta'mül itu di lakukan oleh

\footnotetext{
${ }^{71}$ Imam Syafi'i, Al-Fiqhul Akbar (Mesir: Perc. Awwabiyah, n.d.). 11

72 Imam Al-Baghawi, Tafsir Al-Baghawi, Juz 4 (Beirut: Dar Ihya al-Turats AlArabi, n.d.). 224
} 
para ulama' salaf, baik dari kalangan sahabat, tabi'in dan generasi setelahnya, ${ }^{73}$ bukankah ini berat? Selain makna istiwa dan yadullah, Salafi juga cenderung memaknai ayat wajbullah dengan wajah Allah secara hakiki, bahkan wajah Allah tersebuh akan bisa dilihat jelas tanpa adanya penghalang kelak di surga, berbeda dengan keyakinan NU, sebagai bentuk konsensus dalam beraqidah bahwa allah tidak membutuhkan apapun dari mahluknya termasuk surga.

Oleh karenanya, pendapat yang moderat bagi penulis adalah dari NU, dengan men- ta'wil bukan berarti kita sesat, melainkan kita berada dijalan aman, sebab ; bagaimana pun pena'wilan tersebut, bukankah bisa diterima oleh logika?, dan jika memang Salafi melarang tafwid \{ diakrenakan bahasa al-Qur'an turun dengan bahasa arab yang jelas, bukankah pen- ta'milan tersebut tidak menyimpang dari segi bahasa?, selain itu bukankah kita juga aman dari menyerupakan Allah dengan mahluk?

\section{Kesimpulan}

Setelah penulis mendeskripsikan serta melakukan analisis komparatif terhadap metode penafsiran Islam Salafi dan Aswaja NU tentang penafsiran ayat mutashābihät fi aș-Sífat melalui berbagai media sosial yang tersampaikan kepada penulis, maka dapat ditarik beberapa kesimpulan yakni : Islam Salafi cenderung memaknai ayat mutashäbihät fi aș-Sijat sesuai dengan dhahir teks dengan tanpa ta'will, ta'thil (menolak teks dhahir). Pemahaman seperti itu dilakukan oleh Islam Salafi dengan alasan tidak merubah sedikitpun apa yang ada di dalam al-Qur'an. Sedangkan Aswaja NU lebih memilih untuk men ta'mil beberapa ayat yang berkonotasi jismiyah. Pemahaman tersebut diambil oleh NU dengan tujuan tidak mengatakan Allah mempunyai organ tubuh layaknya manusia dengan beberapa pertimbangan. Islam Salafi meyakini bahwa Allah berada di Arsy, memiliki tangan, memiliki wajah dan memiliki mata, sedangkan NU meyakini bahwa Allah ada tanpa tempat, sedangkan ayat mubkam tentang Allah tidak sama dengan mahluk dan ayat-ayat lain yang mubkam lebih

\footnotetext{
${ }^{73}$ Dikutip dari https://www.ngopibareng.id/timeline/asyairah-sesat-karenamelakukan-takwil-835497 pada 23-April-2021.
}

176 | Mushaf: Jurnal Tafsir Berwawasan Keindonesiaan Volume 1. Nomor 2, Juni 2021. 
diutamakan daripada ayat mutashäbihät yang berkonotasi bahwa Allah memiliki anggota sama dengan mahluk.

\section{Daftar Pustaka}

Abu Fadl Muhammad ibnu Manzhur. Qamus Lisan Al-Arab. Jilid 6. Beirut: Dar as-Ṣadir, 1410.

Al-Akk, Khalid Abdurrahman. Usūul Al-Tafsì Wa Qawäiduh. Beirut: Dar an-Nafāis, 1986.

Al-Aql, Nashir bin Abdul Karim. Islamiyyah La Wahabiyyah. Juz 1. Eropa: Dar Al-Kunuz Asbiliya, n.d.

Al-Asfahānī. Mufradāt Fì Gharīb Al-Qur'an. Juz 1. Damaskus: Dar Al-Qalam, 1412.

Al-Baghawi, Imam. Tafsir Al-Baghawi. Juz 4. Beirut: Dar Ihya alTurats Al-Arabi, n.d.

Al-Buthi, Said Ramadhan. Al-Salafiyyah Marhalab Zamaaniyyah Mubaarokah là Madz̧hab Islami. Damaskus: Dar al-Fikr, 1996.

Al-Dhahabi, Imam. Al-Arsy Li Al-Drahabi. Juz 1. Madinah: Dekan Universitas Islam, 2003.

Atabik, Ahmad. "CORAK TAFSIR AQIDAH (Kajian Komparatif Penafsiran Ayat-Ayat Aqidah)." ESENSLA: Jurnal Ilmu-Ilmu Ushuluddin 17, no. 2 (2016): 209. https://doi.org/10.14421/esensia.v17i2.1288.

Az-Zarqani. Manābil Al-Irfan. Juz 2. Beirut: Dar al-Kitāb al-Arabī, 1995.

Bāz, Ibnu. Majmu' Fatāwa Ibnu Bin Baz: Juz 3., n.d.

Basid, Abd. "PENINGKATAN TARIF HIDUP LAYAK MELALUI PRODUKTIVITAS BEKERJA PERSPEKTIF AL-QUR'AN." Jurnal Studi Ilmu-Ilmu Al-Qur'an Dan Hadis 21, no. 1 (2020): 173-92.

Daud, Abu. Sunan Abu Daud. Juz 4. Beirut: al-Maktabah al-'Isriyah, n.d.

Dhaif, Syauqi. Mu'jam Al-Wasit. (Mesir: Maktabah Syurūq AdDauliyyah, 1425.

Fawaid, Ahmad, and Thoriqotul Faizah. "A Sociolinguistic Analysis of Sword Verses." Al Quds Jurnal Studi Al-Qur'an Dan Hadis 5 (2021): 119-40. https://doi.org/1 http://dx.doi.org/10.29240/alquds.v5i1.2315. 
Fawaid, Ahmad, and Nafi'ah Mardlatillah. "Bias Ideologis Tafsir Hizb Al-Tahrīr.” MAGHZA: Jurnal Ilmu Al-Qur'an Dan Tafsir 5, no. 2 (2020): 184-209. https://doi.org/10.24090/maghza.v5i2.4243.

Imām Muslim. Shahīh Muslim. Juz 3. Beirut: Dar Ihya al-Turats al'Arabī, n.d.

Imam Muslim. Shahib Muslim. Juz 4. Beirut: Dar Ihya al-Turats al'Arabī, n.d.

Iyāzī, Muhammad 'Ali. Al-Mufassirün, n.d.

Ke-40, Panitia Harlah NU. "Sedjarah Ringkas Nabdlatul Ulama" Dalam Chairul Anam, Pertumbuhan Dan Perkembangan NU. Surabaya: Duta Aksara Mulia, 2010.

Muhammad bin S alih al-Utsaimin. Syarah Taqrïb Al-Tarmudziyah.

Saudi: Lembaga Informasi Syaikh Muhammad bin S\}alih alUtsaimin, n.d.

Muhammad bin Shalih al-Utsaimin. Tafsir Surat Al-Maidah. Juz 2. Dar Ibnu al-Jauzi, 2003.

Muhammadin. "PANDANGAN ULAMA TERHADAP

DAKWAH SALAFIYAH.” JIA 53, no. 4 (2017): 130.

S \}alih, Abdul Fatah bin. Al-Tajsim Wa Al-Mujassimah. 2010 M.

Beirut: Resalah Publisher, 2010.

Syafi'i, Imam. Al-Fiqhul Akbar. Mesir: Perc. Awwabiyah, n.d.

Tim harakah islamiyah. Buku Pintar Salafi-Wahabi. Harakah Islamiyah, n.d.

Zahrah, Muhammad Abu. Tarikeh Al-Madhähib Al-Islämiyyah Fì AlSiyāsah Wa Al-'Aqäid, Wa Tarikh Al-Madhähib Al-Fiqhiyyah. Kairo: Dar al-Fikr al-'Arabī, n.d.

Zaidan, Abdul Karim. Al-Wajìz. Fì Ushūl Al-Fiqh,. Beirut: Muassasah ar-Risālah Nāsyirūn, 2012.

\section{Referensi Website}

https:/ /www.youtube.com/watch?v=0nwEUxcqHqA

http://illsionst.blogspot.com/2011/06/sejarah-danperkembangan-nu.html.

https://www.academia.edu/11714294/dinamika_pemikiran -NU.

http:/ / www.nu.or.id/post/read/94919/dua-sikapahlussunnah-tentang-sifat-khabariyah-allah. 
https://islamqa.info/id/answers/145804/penjelasantentang-sifat-istiwa-betis-wajah-adalah-milik-allah-apakah-tubuhtermasuk-sifat-allahtaala?fbclid=IwAR0ssHeOgBr9lvFHMHL5FwlidDvS9YfebDTK MdQ5QkCm3pSOqmNFv-MiVC4 .

https:/ / muslim.or.id/56-sifat-istiwa-allah-di-atas-arsy.html.

https:/ / firanda.com/1829-antara-ust-abdul-somad-ma-mutazilah-imam-abul-hasan-al-asy-ary-pro-nabi-sahabat-serta-imamimam-salaf.html .,

https:/ / www.youtube.com/watch?v=F7ziQtE5HzI.

https:/ / muslim.or.id/56-sifat-istiwa-allah-di-atas-arsy.html

https://www.youtube.com/watch?v=QpuJ15XZ_Ak

https://muslim.or.id/32468-apa-itu-kursi-allah.html http://asysyariah.com/dua-tangan-allah/ pada

https:/ / salafy.or.id/blog/2005/02/25/mengimani-akansifat-kedua-tangan-allah-taala/ .

https:/ / muslim.or.id/64-apakah-allah-memiliki-wajah.html,. https://khotbahjumat.com/3772-memandang-wajah-allahanugerah-terbesar-di-surga.html

https:/ /www.facebook.com/groups/165106884207146/per malink/272616116789555

http:/ / abul-jauzaa.blogspot.com/2011/07/sifat-mata-bagiallah.html

https:/ /islam.nu.or.id/post/read/94919/dua-sikapahlussunnah-tentang-sifat-khabariyah-allah

https://islam.nu.or.id/post/read/94918/bolehkahmengatakan-allah-bersemayam-di-atas-arasy

http:/ / www.piss-ktb.com/2013/02/2222-kajian-tauhidallah-ada-tanpa.html

https:/ / www.youtube.com/watch?v $=874 \mathrm{tWRRMO8s}$

http://www.piss-ktb.com/2012/02/337-pengertian-tanganallah-swt.html?fbclid=IwAR25wcMgiBKZZOzCVWrge3dRCSqm2A9p9zSXTTfW0y6EWqdnGwoexee-64.

https:/ / www.youtube.com/watch?v=2fKyrzQdkPY

https:/ / al-waliwisy.blogspot.com/2014/11/arti-wajah-allahdalam-al-quran.html?m=1\&fbclid=IwAR1v2J3ZfEGwuFadzkiOZdXyqmOgPVp1_wRD9ArNIj0RbkCGjzuMjR -L-U. 
https:/ /www.youtube.com/watch?v=2fKyrzQdkPY https://islam.nu.or.id/post/read/95849/kapan-kitadianggap-menyerupakan-allah-dengan-makhluk https://islam.nu.or.id/post/read/95849/kapan-kitadianggap-menyerupakan-allah-dengan-makhluk

https:/ /www.ngopibareng.id/timeline/asyairah-sesatkarena-melakukan-takwil-835497 